\title{
Teacher Challenge and Tech Issues in Online Schools
}

\author{
Nur Aisyah Zulkifli ${ }^{*}$, Mardia Hayati ${ }^{2}$, and Mirawati ${ }^{3}$ \\ ${ }^{123}$ Universitas Islam Negeri Sultan Syarif Kasim Riau, Indonesia \\ *Corresponding author. Email: nur'aisyah.zulkifli@uin-suska.ac.id
}

\begin{abstract}
While the study on distance learning and its challenges has proliferated, this study describes how teachers confide in the challenges of teaching when schools close and tech issues during the pandemic. Drawing upon the source of data, including an online survey via telephone interviews and Google meet online video conferencing. This case study examines how (1) Online teaching during COVID-19 school closure; and (2) Teacher responses related to challenges and tech issues during online schooling. Teacher challenges and tech issues within each indicator explored sudden changes that make teachers and students learn to adapt to online school. The findings show that the relationship between teachers and technology become interconnected in a dynamic and complex way when implemented in a pandemic situation. It provides pedagogical implications about teachers need technology support, training, and teacher beliefs to integrate pedagogy and technology in the teaching and learning process.
\end{abstract}

Keywords: teacher challenge, tech issues, online school

\section{INTRODUCTION}

The impact of Covid-19 pandemic has changed teaching and learning activities during the last six months. In Indonesia, especially, online schools become an option for the ministry of education and culture to prevent the spread of the Covid-19 virus. Online schools are considered as the best solution to avoid the potential spread of coronavirus in the school environment. The online school has been carried out by various levels of education from early childhood education to tertiary levels. Consequently, studying at school is eliminated as is customary for teachers and students.

Online schools are indeed expected to replace faceto-face learning and delivery of material following the applicable curriculum. The teachers are supposed to rethinking teaching method to fit the online learning format. The teacher has to redo to design the lesson plan that adopts the technology in classroom practice. Through technology, teachers are assisted in online teaching and delivery methods.

However, the difficult choices in the midst of Covid-19 conditions make the learning process seem to be forced at first sight to keep up with the current situation. It is not only in Indonesia, but also all over the world. There is uncertainty and conflict about how to teach, what to teach, the teaching atmosphere, the workload of teachers and students, and the consequence for education equity[1].

The unexpected change to online learning became polemic and challenges for the teachers. The policies issued certainly cannot ensure that everything will run properly in all circles. It is not as effective as conventional learning[2]. However, when changing to online schools, the government required to assume how effective the activities[3].

Online schools that have not been adequately prepared certainly has an impact on the teaching and learning process. Lack of facilities in the form of integrated technology to support the online learning process and adequate facilities between teachers and students does not rule out the possibility learning process. Online learning is not as effective as expected. It becomes problematic when face-to-face interaction does not happen. Lack of understanding to manage and use technology makes it more complicated to achieve learning targets. It is feared that there are teachers giving assignments to students without a guidance process. So that it makes students overwhelmed and has difficulty understanding learning.

This study is considered to uncover issue in online schools during Covid 19 pandemic, which in turn could be used by stakeholder for several reasons. As in many countries studies conducted to analyze the situation online learning during the COVID-19 pandemic [4], [5], [6], the challenges of online learning during the COVID-19 Pandemic[7][8], and impact of psychology on students and teacher [9].

\section{METHOD}

Design

This study is qualitative research with a case study type. The cases studied were teachers' challenges and tech issues faced by teachers in online school during a pandemic Covid 19. In line with, case studies are a strategy of inquiry to collect detailed information about elementary school teachers' challenges and tech issue in online school bounded by time and place. Online schools are conducted 
in several schools in Pekanbaru as an effort to break the chain of the spread of Covid-19 in the school environment. Online school in this study means to carry out distance learning from home by utilizing online applications as a teaching media. This study attempts to understand more about teachers' problem in undergoing online schooling activities which in turn could be used by stakeholder for several reasons

\section{Participants}

This study used random sampling because the researcher cannot control who and from which school the respondent came from. The participants do not limit whether they come from public schools, private schools, Islamic schools. Researchers only restrict and ensure that the subjects used in this study are elementary school teacher in Pekanbaru. The total number of respondents was 25 elementary school teachers in Pekanbaru.

\section{Research Instrument}

The instrument used in this study is an online survey. The data was collected via telephone interviews, and Google meets online video conferencing. The aspects that were asked in the interview were: (1) Online teaching during COVID-19 school closure; and (2) Teacher responses related to challenges and tech issues during online schooling. Analysis of research data was carried out using the Miles \& Huberman analysis model, which consisted of three stages, namely data reduction, data display, and conclusion drawing and verification[6].

\section{FINDING AND DISCUSSION Online teaching during COVID-19 school closure}

The Covid-19 pandemic has adverse effects on education and development. It has paralyzed teaching and learning activities in educational institutions. School closures are implemented from early childhood education to tertiary education. The results showed that many schools had implemented full online learning activities [10]. A lot of influence is generated from this maximum online learning. Nonetheless, it was found a few schools that still carry out teaching and learning activities at school.

As a response to the COVID-19 crisis, the education implementation scheme is expected to adopt alternatives to face-to-face teaching and learning through online activities to allow teaching to continue despite school closures. Online schools are a solution to maintain the development of student skills and knowledge during school closure. The concern that online learning is less than optimal than face-to-face teaching cannot be avoided. Lack of adequate preparation among teachers and students was evident after this semester. However, it is considered an alternative to no schooling.

Furthermore, the application of education policies in an emergency period for the spread of coronavirus disease (Covid-19) based on The Minister of Education and Culture of the Republic of Indonesia issued Circular Number 4 of 2020 is the process learning from home is carried out with the following conditions: (a) Learning from home through online / distance learning implemented to provide a meaningful learning experience for students, without being burdened with demands to complete all achievements curriculum for class promotion and graduation; (b) Learning from home can be focused on life skills education, including regarding the Covid-19 pandemic; (c) Home learning activities and assignments can vary between students, according to their interests and conditions, including considering gaps in access / learning facilities at home; (d) Evidence or the products of learning activities from home are given qualitative feedback from the useful feedback from the teacher, without being required to provide a quantitative score.

Based on the survey, Schools in Pekanbaru has been starting to implement emergency curricula for distance learning. Pekanbaru government has yet to grant permission for face-to-face schools. The aim of the curriculum in special conditions implementation is to give flexibility for academic units to set the curriculum in line with students' learning needs. In the emergency curriculum, not all of the subject matter in the 2013 Curriculum is given to students. There is a reduced lesson load or simplification of essential competencies for each subject. Based on the information obtained, the school currently has implemented an emergency curriculum. Schools are given the freedom to choose their own curriculum outcomes. Among them can be adjusted to the existing target Curriculum 13.

Moreover, the finding showed that the teachers used video conferencing to explain and to present the material for the students. The teacher needs platforms or online applications to facilitate collaborative teaching and learning processes[11] - the application used by the teachers such as zoom cloud meeting, Google meet and WhatsApp video call. Besides, the teachers also used quizzes application and Google classroom to complete the presentation assignment allows the students to compete with each other. It cannot be denied; the teachers and the students got benefit from the application. The can conduct discussions, and stay in contact with the students to teach the material anywhere and anytime.

One by one, the problem emerged, and it became a challenge [7] faced by teachers during the school closure. According to the teachers, a reduction in lesson content can reach $20-40 \%$ of the subject. A problematic situation is 20 $30 \%$ of students are not actively involved when interacting and completing assignments. Thus, it was found that the development of the student learning process did not occur optimally as long as the school was closed.

\section{Challenges in Issues in Online Schools}

Distance learning is nothing new in the educational world. However, teaching remotely to all students in one 
class for one semester presents a unique challenge that only a limited number of institutions can fully address. Schools try to displacement what they have been doing in the real world into the virtual through an online application.

The success of online learning during the Covid-19 period depends on the discipline of all parties. Teachers should be aware of the significant and the benefit of technology as a tool of up-skilling teaching proficiency to support the online school. Effective learning and collaboration outside the classroom are needed for the online classroom. Therefore, before using the technology, the teacher should focus on pedagogy and understanding, rather than technology. In line with the pandemic situation, the teachers suggest modifying their teaching techniques and approach that appropriate with the students.

There are two challenges faced by teachers when attempting to integrate technology in the classroom. The challenges involved external and internal challenges [12]. The external challenge is the institutional level and changes, includes the challenge of access, inadequate training related to technology, and tech support. The internal challenge refers explicitly to teachers, their beliefs, and their knowledge. It includes teacher attitudes and beliefs, confidence in skills and knowledge given, incorporation of technology and learning, and teacher resistance to technology in the classroom browsing. Based on the survey, there was no teachers challenge and tech issues related to online school on confidence in skills and knowledge given. So, it is not discussed.

\section{External Challenges}

\section{The challenge of access}

Based on the result of the online survey, it was found the data, most of the students and teachers in Pekanbaru faced the problem deal with a slow internet connection. They felt disappointed because they cannot join online learning activities. Besides, teachers often get messages from parents to communicate that their children cannot attend online class due to internet access.

Regarding challenges and issues on internet access, according to the teacher, they conducted the learning based on video and photo submissions or direct information conveyed by parents via telephone. If the learning process used video conferencing such as zoom or Google meet, either teachers or students are disabled to access the application

\section{Inadequate training related to technology}

In the information age, it is emerging new technologies that support the educational process, provide opportunities for students to learn, and improve teacher capabilities in teaching using digital media. Technology plays various roles in the process of teaching-learning. Therefore, teachers should improve their pedagogical practice and complete them with the knowledge and ability to utilise different technologies to access, analyse, construe process and spread information to students[13].
Based on the instructions of Pekanbaru city education Youth and Sport Regional, the 2020/2021 Academic Year started online as a result of the Covid-19 pandemic and schools closure. It requires teachers and students to get used to using applications that can help run online schools optimally. For most teachers who are familiar with the use of technology in online/virtual teaching, it is certainly not a problem, but some others don't know what to do.

The teachers said that we have enormous challenges regarding the use of technology during online schools. Some teachers may have training from the education region and school, or training provided by lecturers from several universities as a form of community service on designing and implementing teaching media. Some, on the other hand, have never attended training on how to make a good and appropriate teaching media. If we are unable to design teaching media, it usually copies from YouTube, downloads it, and share it with students via WhatsApp. The findings of this study explored that teachers are eager to be creative with new technology in the online classroom, but they deal with barriers[13] inadequate training related to technology

\section{Tech support}

Tech support provides the potential to improve learning outcomes. It also enhances teacher professionalism. As tech support, no specific application is required to teach in an online school. Yet, it is apparent teachers have limitations in understanding and explaining the material being appropriately trained. Technology support can make teachers focus on teaching and learning process and less worry to students learning development. It is because the teachers have been provided by the government free educational application and internet data packages.

Free internet quota assistance is provided by the government through the Ministry of Education and Culture for teachers, lecturers and students until December 2020[14]. The government has partnered with the EdTEch Company to improve teachers' ability to deliver technology-focused content. Many websites and video conferences can be accessed by the teacher using free internet quota from Ministry of Education and Culture like Cisco Webex, Google Meet, Jitsi Meet, Microsoft Teams, Skype, U Meet Me, and Zoom[15]. Unfortunately, based on the survey, free internet quota cannot be used because of low internet connection. Besides, the education website suggested by the Ministry of Education and Culture sometimes inappropriate with teaching material. The phenomenon becomes a reminder of the inadequacy of resources in educational institutions in line with inadequate access to join in online school 


\section{Internal Challenges}

Teacher attitudes and beliefs

Attitudes and beliefs refer to pedagogy and educational technology to run the technology. It becomes the significant factors to ensure the role and effectiveness of technology in classrooms. In this point, the challenge related to the best way to use the technology, instead of technology used. In this point, the researcher highlights the case where the teacher was facilitated by free zoom meeting from the school; online learning was held from 8.00 am to $12.00 \mathrm{pm}$. The survey was found that $50 \%$ of students did not join zoom meeting. This seems to be a problem in teacher pedagogy and educational technology. On the other hand, there were teachers who used WhatsApp only to send the information to the parent relate to students learning development. While the assignments were given using students workbook. Parents take the work to the school; then the work is done by students at home. Supposedly, teachers can use WhatsApp to convey student assignments. So, the parents do not have to pick up student's assignments to school. This is also one way to break the chain of spreading Covid 19. In line with educational technology issues, teachers' creativity should appear in education systems [16] based on the Ministry of Education and Culture policies

\section{Incorporation of technology and learning}

The teacher is the main factor in student successthe teacher act as a facilitator of the learning process. Incorporation of technology and learning set up the chance to participate directly with students obstacles adjusting student needs, to complement objectives, and to answer external challenges and expectations. The survey answered that teachers have difficulty conducting online school and tend to focus on completing the curriculum. Besides, teachers did not meet the teaching load due to lack of learning time. Incorporation of technology and learning becomes problematic because it does not have experience and preparation, even though the government has issued an emergency curriculum related to Covid 19

\section{The workload of the teacher and the integrating of technology}

As stated before, the last point of internal challenges and issues in the classroom is teacher resistance to technology in the classroom. However, the survey result showed significant challenges faced by teachers today are the workload and technology integration based on the needs of students and the curriculum. If the teacher is demanded to design teaching media based on the curriculum, he/she will do it. Even he/she has limitations to organize teaching media. He/she can browse from the internet and share it to students via WhatsApp, or an online application that has been accepted by the school. The current problem is that the media distributed does not motivate students to learn, because they are bored with learning online for one semester.
Furthermore, Nadiem appealed to teachers to help students affected by the Covid-19 pandemic and potentially left behind by it[17]. Each teacher is asked to do a diagnostic assessment (cognitive and non-cognitive) of students as a product of online school. A non-cognitive review is to assess students' psychological aspects and emotional condition. These include the psychological and socialemotional well-being of students, the enjoyment of students learning from home, and the condition of the students' families. At the same time, cognitive assessment is aimed at testing students' learning abilities and outcomes. The results of the evaluation are applied as the basis for selecting learning strategies and providing remedial or additional lessons for students who are most left behind. Thus, teachers do not have to meet the workload of 24 hours face to face in a week in order to the teachers are able to focus on giving an interactive class to students without the need to pursue hours.

The results indicate inversely proportional to what has been suggested by the minister of education. There are still teachers who meet the achievement targets in the curriculum to maximize workload and are negligent in using technology to support diagnostic assessments.

\section{CONCLUSION}

All institution has followed the government's appeal to implement online schools or distance learning in Indonesia. However, it was found that teacher challenges and tech issues in implementing online schools, mostly how the teaching and learning process is carried out every day, in order to break the chain of the covid-19 virus. This study explores two challenges faced by teachers when attempting to integrate technology in the classroom. First, the external challenge involves access, inadequate training related to technology, and tech support. Second, the internal challenge includes teacher attitudes and beliefs, incorporation of technology and learning, and teacher resistance to technology in the classroom browsing, and workload of teacher and the integrating of technology. As the teacher said that I am not from the informatics engineering department, facing this online school makes me a little stressed because I have to practice applications and accommodate student learning online. The other teachers said that I have to think about how students engage in discussion and interact while learning online. This includes how students have self-motivation to learn. It provides pedagogical implications about teachers need technology support, training, and teacher beliefs to integrate pedagogy and technology in the teaching and learning process.

\section{ACKNOWLEDGMENT}

We gratefully thank to all of the teachers who have participated to finish this study. All the information provided is meaningful. 


\section{REFERENCES}

[1] W. Ali, "Online and Remote Learning in Higher Education Institutes: A Necessity in light of COVID-19 Pandemic," High. Educ. Stud., vol. 10, no. 3, p. 16, 2020, doi: 10.5539/hes.v10n3p16.

[2] M. Adnan, "Online learning amid the COVID19 pandemic: Students perspectives," J. Pedagog. Res., vol. 1, no. 2, pp. 45-51, 2020, doi: 10.33902/jpsp.2020261309.

[3] G. Basilaia and D. Kvavadze, "Transition to Online Education in Schools during a SARSCoV-2 Coronavirus (COVID-19) Pandemic in Georgia," Pedagog. Res., vol. 5, no. 4, 2020, doi: $10.29333 / \mathrm{pr} / 7937$.

[4] S. Dhawan, "Online Learning: A Panacea in the Time of COVID-19 Crisis," J. Educ. Technol. Syst., vol. 49, no. 1, pp. 5-22, 2020, doi: $10.1177 / 0047239520934018$

[5] D. L. Mishra, D. T. Gupta, and D. A. Shree, "Online Teaching-Learning in Higher Education during Lockdown Period of COVID-19 Pandemic," Int. J. Educ. Res. Open, p. 100012, 2020, doi: 10.1016/j.ijedro.2020.100012.

[6] A. Sadikin and A. Hamidah, "Online Learning in the Middle of the Covid-19 Pandemic," BIODIK J. Ilm. Pendidik. Biol., vol. 6, no. 2, pp. 214-224, 2020, doi: 10.17509/t.v6i2.20887.

[7] R. M. Simamora, "The Challenges of Online Learning during the COVID-19 Pandemic: An Essay Analysis of Performing Arts Education Students," Stud. Learn. Teach., vol. 1, no. 2, pp. 86-103, 2020, doi: 10.46627/silet.v1i2.38.

[8] J. König, D. J. Jäger-Biela, and N. Glutsch, "Adapting to online teaching during COVID-19 school closure: teacher education and teacher competence effects among early career teachers in Germany," Eur. J. Teach. Educ., vol. 43, no. 4, pp. 608-622, 2020, doi: $10.1080 / 02619768.2020 .1809650$.

[9] A. Irawan, Dwisona, and M. Lestari, "Psychological Impacts of Students on Online Learning During the Pandemic COVID-19," KONSELI J. Bimbing. dan Konseling, vol. 07, no. 1, pp. 53-60, 2020, doi: https://doi.org/10.24042/kons.v7i1.6389.

[10] B. Setiawan and V. Iasha, "COVID-19 PANDEMIC: THE INFLUENCE OF FULLONLINE LEARNING FOR ELEMENTARY SCHOOL IN RURAL AREAS," J. Pendidik. Sekol. Dasar, vol. 6, no. 2, pp. 114-123, 2020.

[11] S. Famularsih, "Students' Experiences in Using Online Learning Applications Due to COVID-
19 in English Classroom," Stud. Learn. Teach. vol. 1, no. 2, pp. 112-121, 2020.

[12] A. M. Johnson, M. E. Jacovina, D. E. Russell, and C. M. Soto, "Challenges and solutions when using technologies in the classroom," Adapt. Educ. Technol. Lit. Instr., pp. 13-29, 2016, doi: 10.4324/9781315647500.

[13] T. Habibu, M. Abdullah-Al-mamuun, and C. Clement, "Difficulties Faced by Teachers in Using ICT in Teaching-Learning at Technical and Higher Educational Institutions of Uganda," Int. J. Eng. Res. Technol., vol. 1, no. 7, p. 1, 2012.

[14] "Bantuan Pulsa Gratis Untuk Siswa, Mahasiswa, Guru Dan Dosen," Inspektorat Jendral Kemendikbud. https://itjen.kemdikbud.go.id/public/post/detail/ bantuan-pulsa-gratis-untuk-siswa-mahasiswaguru-dan-dosen (accessed Nov. 10, 2020).

[15] "Bantuan Kuota Data Internet 2020," Kementerian Pendidikan dan Kebudayaan, 2020. https://kuota-belajar.kemdikbud.go.id/.

[16] D. Henriksen, M. Henderson, E. Creely, S. Ceretkova, M. Černochová, and E. Sendova, "Creativity and Technology in Education: An International Perspective," Technol. Knowl. Learn., vol. 18, 2018, doi: 10.1007/s10758-0189380-1.

[17] Z. Wuragil, "Pandemi, Menteri Nadiem Kurangi Beban Kerja Guru Tapi Minta Lakukan Ini," TEMPO.CO, Jakarta, Aug. 2020.

[18] J. w Creswell, Educational Research: planning, conducting, and evaluating quantitative and qualitative, 4th ed. Boston: PEARSON, 2012.

[19] L. Liu, "Using Generic Inductive Approach in Qualitative Educational Research: A Case Study Analysis," J. Educ. Learn., vol. 5, no. 2, p. 129, 2016, doi: 10.5539/jel.v5n2p129. 